\title{
Central venous catheter malposition
}

\section{Santral venöz kateter malpozisyonu}

\author{
Onur Avcı ${ }^{1}$, Salih Yildırım ${ }^{1}$, İdris Erșan ${ }^{1}$, Canan Baran Ünal ${ }^{1}$, Mehmet Fatih Yörüi ${ }^{1}$
}

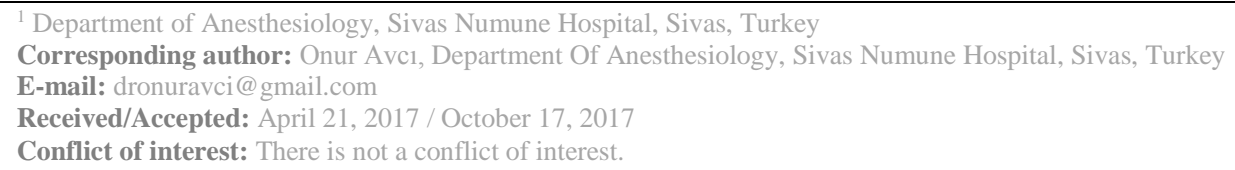

\section{SUMMARY}

Central venous catheter (CVC) is a process used on patients who need continous intravenous medication and nutrition support. Seldinger percutaneous technique is often used to place the central venous catheter. Internal jugular vein, femoral and subclavian vein are used the most. Life threatening complications are seen more frequently in patients with central venous catheterisation. Short term compications are; artery punction, pneumothorax, hemothorax, arythmia, tamponade, air embolism, nearby nerve injury, guide wire staying inside the vein, aorta injury, catheter rupture, vein or atrium perforation. In long term, arteriovenous fistula, arterial and venous aneurism, venous trombose and various infections can occur due to catheter location and duration. A woman with central venous catheter swivel was reported in this case.

Keywords: Central venous catheter, complications, pneumothorax

\section{ÖZET}

Santral venöz kateter (SVK), sıklıkla hastaya devamlı intravenöz medikasyon, beslenme desteği gerektiğinde başvurulan bir işlemdir. Santral venöz katateri yerleştirmek için Seldinger yöntemi olarak bilinen perkütan giriş tekniği en yaygın olarak kullanılan yöntemdir. En sik internal juguler ven, femoral ve subklaviyen ven kullanılmaktadır. Daha seyrek olarak eksternal juguler ven, sefalik ve bazilik venler kullanılmaktadır. Hayatı tehdit eden komplikasyonlar santral venöz kateterizasyon uygulanan hastalarda daha sık görülmektedir. Erken dönem komplikasyonlar; arter ponksiyonu, pnömotoraks, hemotoraks, aritmi, tamponad, hava embolisi, komşu sinir yaralanması, kılavuz telin damar içinde kalması, aort yaralanması, kateter kopması, ven veya atriyum perforasyonudur. Uzun dönemde ise kateterin uygulama yerine ve kalış süresine bağlı olarak arteriyovenöz fistül, arteriyel ve venöz anevrizma, venöz tromboz ve çeşitli enfeksiyonlar görülebilir. Bu yazıda, santral venöz kateteri kendi etrafinda dönen bir bayan hasta sunuldu.

Anahtar sözcükler: Santral venöz kateter, komplikasyonlar, pnömotoraks

\section{INTRODUCTION}

Central venous catheterisation (CVC) is frequently used in open heart and aorta surgeries, intensive care patients and patients with chronic renal failure (CRF). While internal jugular vein (IJV) and femoral and subclavian veins are used the most, external jugular vein (EJV), cephalic and basilic veins can also be used. Seldinger technique is the most preferred one. Central venous catheterisation can cause various complications. Anatomic structure, experience of the personnel and quality of the products are important factors for the occurrence of complications ${ }^{1-3}$. In this case with
CVC, we observed a wrong placement of the catheter and discussed these cases in the light of the information in literature.

\section{CASE PRESENTATION}

CVC with Seldinger method on right subclavian vein was planned for a 40 year old woman patient, who was being monitored in the intensive care unit after sudden cardiac arrest. Hemostasis parameters values were normal. During the procedure, patient's right shoulder was elevated to find the right subclavian vein and a guide wire was sent into the vein. There were no problems during this 
procedure. A 3 way central catheter was advanced with the guide wire. At the end of the procedure, the catheter was fixed after blood came out. A chest X-Ray was taken for control before usage and it was observed that the catheter was in place, but it turned around itself in vena cava superior and that it malpositioned towards the right jugular vein (Figure 1). Once sterilisation was achieved again, the catheter was pulled back a little. The catheter was pulled back and was placed a second time with the help of a guiding wire. In a second X-Ray, the placement was right and usage of the catheter was permitted (Figure 2). No complications occured before or during the procedure. The patient relatives approved for publication of the scientific data belonging to the patient.

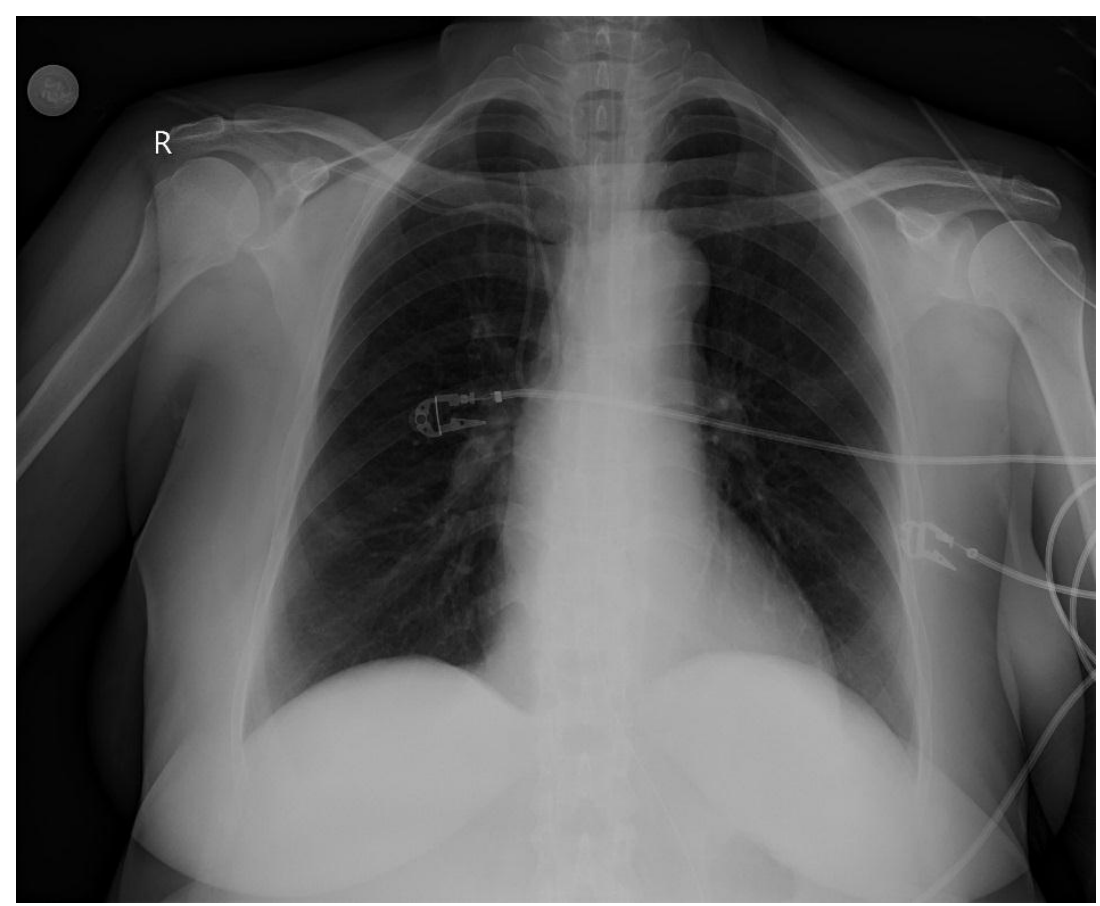

Figure 1: Central venous catheter turning around itself in vena cava superior and malpositioning towards right jugular vein in a posteroanterior chest $\mathrm{x}$-ray.

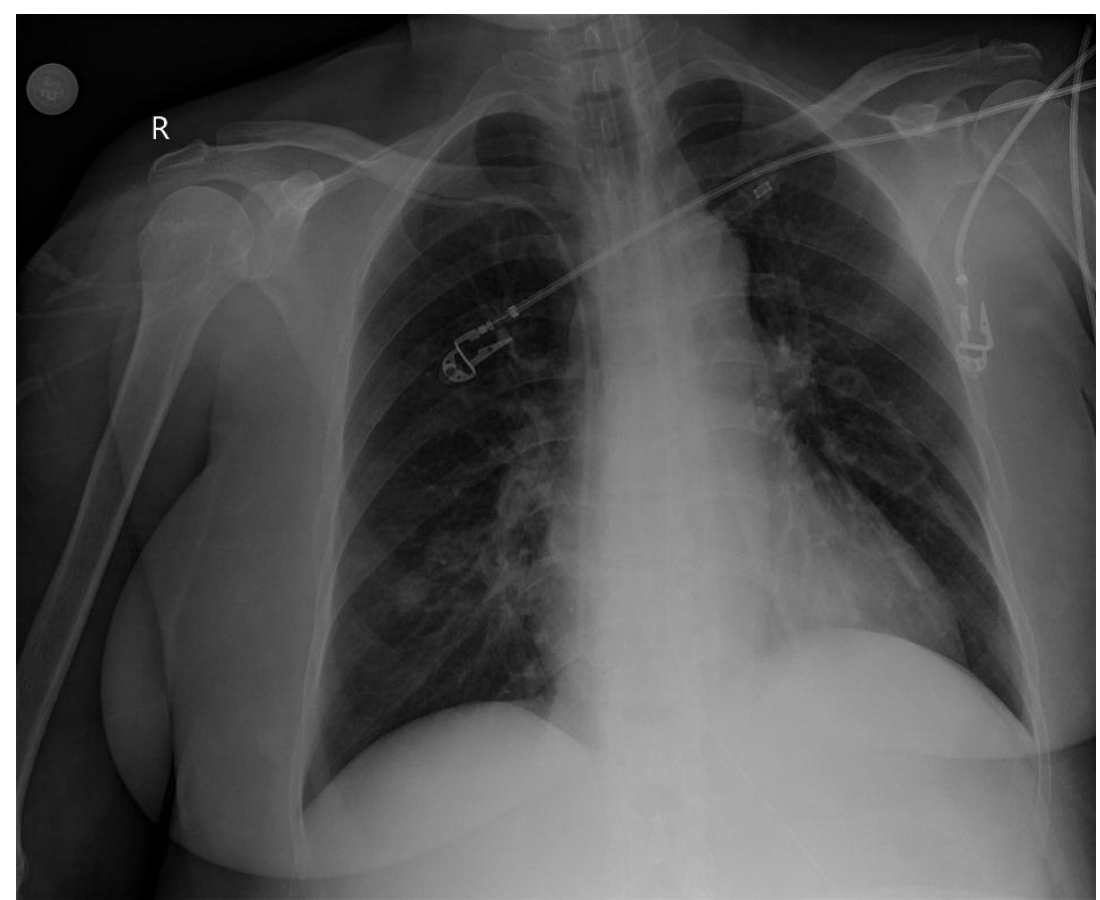

Figure 2: Image of repositioned central venous catheter placed throough right subclavian vein in the control posteroanterior chest $\mathrm{x}$-ray. 


\section{DISCUSSION}

CVC is frequently used for hemodynamic monitoring, parenteral nutrition, venous pacemaker placement, temporary dialysis catheter placement for hemodialysis, especially in intensive care units. Infection, arythmia, hematoma, pneumothorax, hemothorax, air or thrombus embolism, nearby nerve or vessel trauma are the most often complications during the procedure and in short term ${ }^{4}$. Aortic injury, vena cava superior perforation, cardiac perforation, cardiac tamponade, pleural effusion, guide wire staying inside the vein and catheter rupture are also some of the complications, however they occur rarely ${ }^{4}$. For short term complications, physician's experience, catheter quality and anatomic location are important factors ${ }^{1,3}$. We think that the reason for the complication in our case is due to lack of experience and lack of equipment quality.

It is possible to diagnose many of the short term complications after central venous catheterisation with a cheap and easy diagnostic tool, X-Ray. It also shows if the placement of the catheter is right. In our case, we were able to see that the catheter's placement was right but it turned around itself and headed towards the right jugular vein. Thanks to early detection and right intervention in our case, there were no complications before and after the procedure.
CVC is a frequently used invasive procedure with high mortality and morbidity complications. For this reason, we think that a procedure done by experienced physicians or under their supervision would reduce complications and that radiologic examinations are necessary for the early diagnose of short term catheter complications.

\section{REFERENCES}

1) Batra RK, Guleria S, Mandal S. Unusual complication of internal jugular vein cannulation. Indian J Chest Dis Allied Sci 2002; 44: 137-9.

2) Morgan GE Jr, Mikhail MS, Murray MJ. Patientmonitors. In: Morgan GE Jr, Mikhail MS, Murray MJ, editors. Clinical anesthesiology. 4th ed. New York: McGraw-HillCompaniesInc; 2006 p. 100-2.

3) Paw HG. Bilateral pleural effusions: unexpected complication after left internal jugular venous catheterization for total parenteral nutrition. $\mathrm{Br} \mathbf{J}$ Anaesth 2002; 89: 647-50.

4) Doğan N, Becit N, Kızılkaya M, Ünlü Y. Santral venöz kanülasyonuna bağlı nadir bir komplikasyon. Türk Göğüs Kalp Damar Cer Derg 2004; 12: 135-7. 